DOI https://doi.org/10.30525/978-9934-26-073-5-2-42

\title{
THE USE OF FEMININITIES AS A RESULT OF ACTUALIZING THE ISSUE OF GENDER EQUALITY
}

\author{
Kuz V. V. \\ Candidate of Philological Sciences, \\ Senior Lecturer at the Department of Linguistics \\ Leonid Yuzkov Khmelnytskyi University of Management and Law \\ Khmelnytsky, Ukraine
}

Equality of rights for women and men implies the absence of privileges or restrictions on the grounds of sex, equal conditions for the exercise of rights. That is, gender equality provides equal conditions for women and men to realize their rights and potential to contribute to national, economic, social and cultural development and the exploitation of results. However, it should be noted that this is a process of fair treatment by society towards women and men in terms of equal status, equal access to resources, goods and services, achieving equal results.

Along with the issues of achieving gender equality, femininities are actively used, not only in terms of the dynamic development of language, but also the identification of a person in terms of determining his position. Particularly noticeable is the active introduction of femininities in the professional activities of public administration, education, law, etc., and in connection with the predominance of positions held by men, respectively, and positions have masculine names.

According to the Global Gender Gap Index, Ukraine's position in the world ranking of 144 countries included in the ranking has significantly deteriorated. Thus, in 2014 Ukraine took 56th place, in 2016 - 69th place, in 2017 the position rose by 8 positions [3]. Among the main factors influencing the fluctuations in the ranking are the economic situation in the country and the percentage of women involved in politics. It is worth noting that women in Ukraine receive on average a lower level of income compared to men, for similar work and perform a significant part of unpaid family work in households [2, p. 42-44].

Analysis of the distribution of jobs by gender shows that if women hold managerial positions, such positions are mostly low, such positions of public managers belong to the middle and lower categories, the importance and participation of which in the decision-making process is insignificant. A similar situation can be observed in the field of politics, in legislative, 
electoral representative bodies of public power. It is also widely believed that women's rights are violated as recipients of social benefits and as workers in the social security system. Such cases occur due to the fact that men are considered the «norm». That is, social rights are linked to the male norm of continuity, full employment. The lower status of women's social rights is due to their low status in political rights and less opportunities to gain power in society compared to men, especially if it is due to their representation in decision-making processes in the state, public institutions.

Analysis of the current legal framework for gender equality in the Concept of the State Social Program for Equal Rights and Opportunities for Women and Men until 2021 [1] shows the lack of a gender component in strategic government programs and the inability of public administrations to implement the principle of equal rights and opportunities for women and men [1].

The media do not stay away from language innovations and are quite gender-sensitive, as they are assigned the role of intensifying the use and identification of femininities in the media space. One of the functions of feminism is to overcome the barriers of language sexism, to reduce the use of masculinities, which, in essence, contribute to the stereotype of the subordination of women, especially with regard to professional titles. The use of femininities makes women visible in society; if words are difficult to perceive, then you should try to find another form, if it is a matter of habit, then it is necessary to use femininities more often and previously unusual words will become the norm.

The use of femininities in all spheres, observance of the rules of gender equality in the personal and public spheres, prevention of gender restrictions in its various manifestations are difficult tasks that are strongly connected with the processes of democratization, observance of civil rights and freedoms, institutionalization of legal society in globalization and informatization.

\section{References:}

1. On the Sustainable Development Strategy «Ukraine - 2020»: Decree of the President of Ukraine of January 12, 2015 № 5/2015. Official Gazette of Ukraine. 2015. № 4. S. 8. Art. 67.

2. Sustainable Development Goals: Ukraine: National Report. Ministry of Economic Development and Trade of Ukraine, 2017. 175 p.

3. The Global Gender Gap Report 2017: Insight Report. Geneva: Switzerland; the World Economic Forum, 2017. 351 p. 